\section{Magma chamber profiles from Bay of Islands ophiolite complex}

CASEY and Karson ${ }^{1}$ have presented a model for the shape and size of magma chambers underlying mid-ocean ridges, based on observations of the Bay of Islands ophiolite. They show that igneous layering in rocks of the plutonic complex is oriented up to $90^{\circ}$ oblique to the palinspastic horizontal, and they use this, and other evidence, to infer that nucleation and growth of crystals occurred in situ on the chamber walls, without the need for settling of crystals.

The magma chamber model of Casey and Karson (Figs 4 and 5 of ref. 1) shows a curious, unexplained and yet crucial feature, namely that while ultramafic rocks were forming along the sides of the chamber near its base, mafic rocks were forming along the sides at higher levels. Neither the effect of pressure nor that of volatile content on crystallization of the magma can be responsible for this difference. If the ultramafic and the mafic rocks indeed formed in the same magma chamber, and if Casey and Karson are correct in saying that crystallization occurred only along the chamber walls, then the magma must have been stratified, with more mafic magma lying below less mafic magma; the 'Unit 2' rocks of the plutonic complex (interlayered mafic and ultramafic rocks) would then represent the junction between the two magma types, that is a zone of mixing.

This inference that the magma was compositionally stratified agrees with that reached by Sparks $e t a l^{2}$ on the basis of the density variation in mid-ocean-ridge basalts.

\section{H. DONALDSON}

Department of Geology,

St Andrews University,

Fife KY16 9ST, UK

1. Casey, J. F. \& Karson, J. A. Nature 292, 295-301 (1981). 2. Sparks, R. S. J., Meyer, P. \& Sigurdsson, H. Earth planet. Sci. Lett. 46, 419-430 (1980).

CASEY AND KARSON REPLYDonaldson's comment that we have inferred the existence of chemical heterogeneity along the margin of the magma chamber which formed the plutonic complex of the Bay of Islands Ophiolite is perhaps an understatement. We categorically stated that "the lack of lateral continuity of the fine-scale layering must be interpreted as the result of fairly significant changes in physico-chemical conditions on a scale approximated by the lateral continuity of the layering $(\sim \leqslant 50 \mathrm{~m})$ ". We also stated that "sig- nificant chemical zonation in the magma chamber" was reflected by the fact "that fine scale igneous layers (which define isochronous planes) strike obliquely across the contacts between major lithologic subdivisions of the plutonic section".

Donaldson has also suggested that this interpretation of chemical zonation is consistent with the work of Sparks et al. ${ }^{1}$ (and presumably Huppert and Sparks ${ }^{2,3}$ ). He has further postulated that the transition zone ('Unit 2') of the plutonic complex can be interpreted as a mixing zone between two distinct magma types. Certainly, Sparks and his co-workers have clearly shown the weaknesses inherent in the arguments which lead to the emphatic statements that mafic magma chambers cannot become chemically zoned because of continuous convective overturn. Based on the extent of lateral continuity of layering throughout the plutonic complex and other factors treated in the original paper, however, we do not believe that one can simply categorize two magma types. The overall chemical and mineralogical zonation of the crystallization products within the plutonic complex seems to span the entire thickness of the plutonic section. Previous geochemical studies ${ }^{4-6}$ and unpublished data collected by us indicate that there is no sharp break in mineral compositions identified at the transition zone. These data seem to indicate that at any single time, the margin of the chamber was in contact with magma of numerous and highly variable compositions. The compositional range seems to depend on stratigraphic height within the plutonic section. The transition zone simply marks the first appearance of plagioclase as a major phase within the plutonic section.

Detailed mineral chemistry studies by our group will attempt to characterize the scale and degree of chemical variations along a single magma chamber profile. Until such time, however, it is premature to suggest a simple model having just two magma types and a single mixing zone. The chamber could be multiply stratified on a fine scale and consist of multiple mixing zones that need not have a steadystate position within the chamber. The dimension of the chamber might also be conducive to local chaotic and laterally discontinuous chemical stratification. These possibilities have not yet been tested by Sparks and co-workers because they have initiated their studies using simple two liquid models. It is also not clear that pressure and volatile content of the magma should be overlooked or discarded as a possible cause for at least part of the chemical and mineralogical zonation until further work, especially trace element and isotopic studies, has been completed. At present there is little evidence to substantiate Donaldson's simplistic model of just two magma types; field and geochemical evidence seems to favour a more complex multiple stratified model.

\section{J. F. CASEY}

Department of Geology,

University of Houston,

Central Campus,

Houston, Texas 77004, USA

\section{J. A \\ Department of Geology and}

Geophysics,

Woods Hole Oceanographic

Institution,

Woods Hole,

Massachusetts 02543, USA

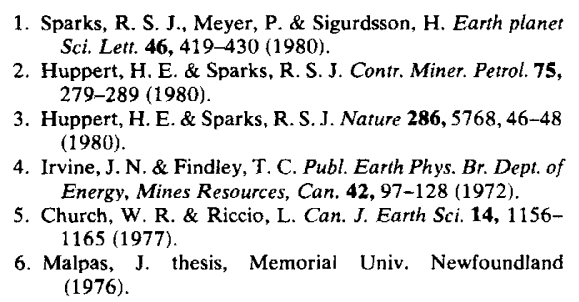

\section{$\mathrm{K}^{+}$depletion and $\mathrm{Na}^{+}$pump density}

IT has been shown ${ }^{1}$ that the skeletal muscles of $\mathrm{K}^{+}$-depleted rats lose large quantities of $\mathrm{K}^{+}$, gain $\mathrm{Na}^{+}$, and many have fewer ouabain binding sites than normal; this is in contrast to the findings of Chan and Sanslone ${ }^{2}$ and Erdman, Bolte and Luderitz ${ }^{3}$ for red blood cells (RBCs) and heart muscle, respectively, of $\mathrm{K}^{+}$depleted rats and in cultured human cells grown in low- $\mathrm{K}^{+}$medium ${ }^{4,5}$.

In our original experiments we showed ${ }^{4}$ that more pumps were produced in cells when the internal $\mathrm{Na}^{+}$concentration $\left(\left[\mathrm{Na}^{+}\right]_{\mathrm{i}}\right)$ was allowed to rise to $20-60 \mathrm{mM}$, with a corresponding drop in $\left[\mathrm{K}^{+}\right]_{\mathrm{i}}$. In recent experiments we have found that very large increases in $[\mathrm{Na}]_{\mathrm{i}}$ (and correspondingly large reductions in $\left[\mathrm{K}^{+}\right]_{\mathrm{i}}$ ) lead to a large loss of ouabain binding sites and transport capacity in $\mathrm{HeLa}$ cells (Table 1). These losses in ouabain binding sites are greater than can be accounted for by cessation of the normal insertion rate of new pumps $\left(1.5 \% \mathrm{~h}^{-1}\right)^{6}$ and imply that an accelerated removal of pumps is occurring.

Our results show that HeLa cells can be made to produce either a greater or lesser density of pumps than normal, apparently depending on the ion concentrations within the cells; they therefore mimic RBCs and heart or skeletal muscles of $\mathrm{K}^{+}$-depleted rats. We suspect that two processes are occurring: (1) as [Na $]_{i}$ rises, the rate of insertion of new pumps increases, and (2) if $[K]_{i}$ falls below a critical level, the synthesis of new pumps stops (because $\mathrm{K}^{+}$is required as a cofactor by most enzymes ${ }^{7}$ ) and pumps are 